\title{
An Ethical View on International Trade Agreements TTIP and CETA in the Republic of Croatia
}

\begin{abstract}
SUMMARY
The topic of TTIP and CETA was almost completely suppressed in Croatia. ${ }^{1}$ Those are very important international agreements which could have far-reaching consequences both for the world and individual countries. Maybe Croatia, as well as the EU, is not so much involved in the whole story concerning TTIP. However, CETA is an agreement signed by Canada with the European Union. Therefore, after the approval of the European Parliament, EU provisions, such as the customs policy, can immediately start to apply, which means abolishing duty rates for $99 \%$ of the products as early as 1 January 2017. The decision on the CETA conclusion on behalf of Croatia was initiated by the technical Government of Tihomir Orešković at its last session. ${ }^{2}$ The superficial interpretation of these certainly not harmless agreements is of too little interest to both philosophers and theologians in Croatia, and except for the Centre of Excellence for Integrative Bioethics'3 reaction concerning this question, other philosophical-theological discussions seem to be lacking. The impression is that philosophers and theologians feel these issues do not concern them. In this paper we will try to make clear that the above-mentioned international agreements concern both philosophers and theologians, and that they certainly should, from their field, from the theoretical level, engage in the discussion of the said agreements.
\end{abstract}

\footnotetext{
" College of Ivanić-Grad, Ivanić-Grad, Croatia. ORCID ID: https://orcid.org/0000-0001-5509-5746.

** Faculty of Humanities and Social Sciences, University of Zagreb, Zagreb, Croatia.

Correspondence Address: Berislav Čović, Faculty of Humanities and Social Sciences, University of Zagreb, Ivana Lučića 3, HR-10000 Zagreb, Croatia. ORCID ID: https://orcid.org/0000-0002-4405-265X. E-mail: berislavc@ gmail.com.

1 Namely, economists have only marginally assessed the impact of these agreements on the signatory states, while the only serious analysis of these agreements was made by the Centre of Excellence for Integrative Bioethics, and especially Dr. Ivica Kelam.

2 A decision to initiate proceedings available at: Government of the Republic of Croatia, available at: https:// vlada.gov.hr/UserDocsImages//2016/Sjednice/2016/42\%20sjednica\%20Vlade//42\%20-\%2019.pdf (accessed: December 10, 2019).

3 Here, we refer to the bioethicist Dr. Ivica Kelam and his research entitled „Investor to State Dispute Settlement. A Challenge for Democracy, Ethics, the Environment, and the Rule of Law", Synthesis philosophica, 34 (1/2019.), pp. 59-71. Available at: https://hrcak.srce.hr/index.php?show=clanak\&id_clanak_jezik=326743 (accessed: December 10, 2019).
} 
Keywords: International trade agreements, TTIP, CETA, Croatia, philosophy, theology, challenges.

\section{What are TTIP and CETA, and which questions they place before philosophy and theology}

The Transatlantic Trade and Investment Partnership (TTIP) is a free trade agreement between the EU and the US. According to its supporters, the goal of this agreement is to secure economic growth through the removal of barriers to free trade, while the opponents claim that the agreement will further increase the power of large capital and make it difficult for governments to regulate the market as a whole according to the national interest. ${ }^{4}$ On the other hand, the Comprehensive Economic and Trade Agreement (CETA) is an agreement between the EU and Canada, signed in 2016, currently being ratified by the parliaments of the EU Member States. ${ }^{5}$ The following is listed as the good side of CETA: lowering customs, opening up the market for services and encouraging investments, mutual recognition of professional qualifications, greater competitiveness of European companies in the Canadian market, access to public tenders for EU companies, lower costs for companies with equally high standards, protection of European innovators, artists, and special European food products and beverages, protection of human rights in the workplace, and environmental protection.

At first, one would not even dare to say anything against such professional and welldesigned positive effects on the signatory states.

Talking about the issue of CETA, the economist Ljubo Jurčić ${ }^{6}$ says for the Večernji list that CETA is a benign version of TTIP. However, Jurčić clearly points out that

4 More on this in: Raza, Werner (project leader) et al. ASSESS_TTIP: Assessing the claimed benefits of the Transatlantic Trade and Investment Partnership (TTIP): Final Report. Vienna: ÖFSE, 2014. Available at: https:// www.researchgate.net/publication/265301168_ASSESS_TTIP_Assessing_the_claimed_benefits_of_the_ Transatlantic_Trade_and_Investment_Partnership (Accessed: December 10, 2019); Capaldo, Jeronim. The TransAtlantic Trade and Investment Partnership: European Disintegration, Unemployment and Instability. Medford: Tufts University, 2014. Available at: file:///F:/TTIP\%20I\%20CETA_RAD/Impact-Study-of-TTIP-on-Employmentand-Wages.pdf Accesed: December 10, 2019.; De Bièvre, Dirk; Poletti, Arlo. „Why the Transatlantic Trade and Investment Partnership is not (so) new, and why it is also not (so) bad", Article in: Journal of European Public Policy, 24(10/2017), pp. 1506-1521. DOI: 10.1080/13501763.2016.1254274.

Available at: file:///F:/TTIP\%20I\%20CETA_RAD/Why_the_Transatlantic_Trade_and_Investment_Partner.pdf (Accessed: December 10, 2019).

5 More on this in: Mertins-Kirkwood, Hadrian; Sinclair, Scott; Trew, Stuart (edt.). Making Sense of CETA. An analysis of the final text of the Canada-European Union Comprehensive Economic and Trade Agreement. 2nd edition. Berlin/Ottawa: PowerShift: CCPA et al., 2016. Available at: http://s2bnetwork.org/wp-content/uploads/2018/11/ Making-sense-of-CETA-2018.pdf (Accessed: December 10, 2019).

6 Sučec, Nikola, „Sporazum o trgovini s Kanadom je potpisan - što to znači za Hrvatsku“, Večernji list, 31.10.2016. https://www.tportal.hr/.../sporazum-o-trgovini-s-kanadom-je-potpisan-sto-to-znaci-za, Accessed: May 10, 2018. 
the agreement does not encroach on the powers of the EU countries, and that each country maintains its sovereignty over the standards and powers in consumer, health, and quality protection. This is nicely put at first glance, but TTIP was promoted similarly or the same.

The main thesis of CETA's advocates is the assurance that the deal will increase the exchange between partners by 20 percent and boost the growth of both economies. ${ }^{7}$ For Canada, the agreement is important because it reduces its dependence on the United States, its main export market.

Thus, authors Maja and Ana Vizjak in the concluding section of the study titled "Pregovori o transatlantskoj trgovini i ulaganju (TTIP) i regulacija financijskog tržišta" ("Negotiations on the Transatlantic Trade and Investment Partnership (TTIP) and Regulation of Financial Market") emphasize that there is a conflict of interest in ensuring equal conditions for all participants in the financial markets and the main goal in terms of profit-making and that corporations, as well as banks, are not capable of successfully managing or regulating the world financial system.

Some members of the Croatian Parliament, e.g. Nikola Grmoja ${ }^{9}$ or Branimir Bunjac, ${ }^{10}$ who characterized it as anti-Croatian and anti-civilization, warned of the serious problem of signing the CETA agreement.

Some members of the UN also warn of the dangers of such agreements, like Alfred de Zayas, who says: "Der TTIP-Deal schadet unsere Demokratie". ${ }^{11}$ Zayas notes that CETA makes the rule of law, but also democracy and human rights questionable.

However, the governments that could and should do the most are retreating when faced with the economic interests of corporations. We have witnessed a silent vote in the Croatian Parliament, some of the authors reported it as a GMO entry through

7 Troszczynska-Van Genderen, Wanda; Bierbrauer, Elfriede, The Transatlantic Trade and Investment Partnership (TTIP): The US Congress's positions. Brussels: Policy Department External Policy - European Parliament, 2014. http://www.europarl.europa.eu/RegData/etudes/BRIE/2014/536395/EXPO_BRI(2014)536395_EN.pdf, Accessed: May 10, 2018.

8 Vizjak, Ana; Vizjak, Maja, „Pregovori o Transatlantskoj trgovini i ulaganju (TTIP) i regulacija financija financijskog tržišta“, Ekonomska misao i praksa, (1/2016), pp. 319-336.

9 Grmoja, Nikola, „Ako je CETA stvarno dobra, zašto to nismo mogli potvrditi?؛, Večernji list, 4.7.2017. https:// www.vecernji.hr/vijesti/nikola-grmoja-most-sabor-ceta-gordan-jandrokovic-1180396 Accessed: May 10, 2018.

10 Romić, Tea, „Bunjac: Sporazum CETA je antihrvatski“, Večernji list, 30.6.2017.

https://www.vecernji.hr/vijesti/sabor-stanke-branimir-bunjac-1179676 Accessed: May 10, 2018.

11 De Zayas, Alfred-Marice, „Angela Merkel und Sigmar Gabriel wollen das Freihandelsabkommen mit den USA durchsetzen. Dabei hilft es nur den Konzernen“, Focus Magazin, (20/2016).

http://www.focus.de/magazin/archiv/die-debatte-der-ttip-deal-schadet-unserer-demokratie_id_5527417.html, Accessed: May 10, 2018. 
the back-door. ${ }^{12}$ Maybe it is good to clarify that in the Croatian Parliament, there was a vote on something that is simply compliance with the EU legislation. Of course, the "opposition" has taken the opportunity to make some "noise", which is normal, because it is time to fight for every possible vote, and that is something the "ruling" would likely do as well if they were the "opposition".

\section{Where is philosophy and what are philosophers doing?}

The demands of philosophy in politics and the economy are hardly worth mentioning. The extent of their mutual relationship is evident based on Aristotle's Ethics and Politics alone. There only remains a question of measuring the stated relationship between ethics, politics, and the economy in our contemporary age, which seems to strive for distancing from the demands of ethics in the direction of the economy (trade, business) and politics as much as possible. ${ }^{13}$

Josip Mužić notes that today, in a technologically advanced century, man faces an ethical challenge, and by quoting authors like Ingmar Persson and Julian Savulescu states that people are "morally ill-suited to such newly created conditions because moral progress has been slower than the technological one, so it is necessary to morally improve man if we want to save our civilization". ${ }^{14}$

Human happiness can be defined by the function that belongs to every human. Every human has to be a part of practical life, and the ultimate good should come from the fact that this function is performed well and needs to be a lifetime constant. The question is how much the TTIP and CETA agreements contribute to the true and genuine happiness of all, and how much they focus on the happiness of some (the most powerful, the great).

12 Kelam says that this is the phenomenon of "land grabbing", where the war for food is waged, but even more for personal interest and profit. More on this in: Kelam, Ivica, "Planet na prodaju - socijalno-etičko razmatranje fenomena grabeža zemlje", Obnovljeni život, 70(1/2015), pp. 101-113. This is also corroborated by Dražen Šimleša when he cites an example of a publication in Croatia in favor of GMO foods and states that behind the introduction of GMOs is actually a war for the fertile ground, which the powerful corporations want to manage. As their power grows, their control of human life will become more dominant. More on this in: Šimleša, Dražen, "Biotehnologija kao oblik kontrole", Socijalna ekologija, 13(1/2004), pp. 25-43, 32.

13 When it comes to the relationship between ethics and ecology, where the requirements for solving problems in the field of ecology are even more significant, a detailed analysis is made by I. Koprek's research entitled „Ekološka etika"see: Vuleta, Bože; Vučković, Ante (ur.), Odgovornost za život. Zbornik. Baška Voda: Franjevački institut za kulturu mira, 2001., pp. 31-43.

14 Persson, Ingmar; Savulescu, Julian "Unfit for the future? Human Nature, Scientific Progress, and the Need for Moral Enhancement”, see: Savulescu, Julian; ter Meulen, Ruud; Kahane, Guy (edt.), Enhancing Human Capacities, Oxford: Wiley-Blackwell, 2011., pp. 486-499; Persson, Ingmar; Savulescu, Julian, Unfit for the future. The Need for Moral Enhancement, Oxford: Oxford University Press, 2012., pp. 100-134, quote according to: Mužić, Josip. Rat protiv covjeka. Zagreb: Glas koncila, 2015., p. 425. 
What we can specifically underline in Aristotle are his thoughts on righteousness. Aristotle develops this conception primarily in Nicomachean Ethics. ${ }^{15}$ For him, righteous is what is lawful and equal, and contrary to that is unlawful and unequal, which would then also be unrighteous. ${ }^{16}$ In short, based on Aristotle's perception of righteousness, we can say that the TTIP and CETA agreements may be lawful, but they hardly follow the field of equality. Hardly could any of Aristotle's virtues (of the middle) be ascribed to the TTIP and CETA agreements. Can these agreements justify Aristotle's thoughts on friendship in the equality between two sides?

Plato also makes it clear what would be a healthy society. When he writes in his Republic ${ }^{17}$ about the good and health of the individual, Plato underscores that what is good for the state should also be good for the individual. By this, he points out that human is a being referred to others, a being of communion. ${ }^{18}$ We can go one step further to say that what is good for one state (TTIP and CETA as interstate agreements) should also be good for the individuals of the mentioned states. ${ }^{19}$ It is difficult to see a genuine desire for a total and individual good in what the said agreements offer. It is more likely that the said agreements are much closer to the phrase "might is right", and more detailed studies are yet to be conducted on the particular traps which the said agreements hide in relation to e.g., the construction, pharmaceutical, financial or agricultural sector. Plato also says that human is distinguished by righteousness when he takes care of others and when he does not isolate himself as a special whole out of the whole of all. ${ }^{20}$ Of course, it is necessary for a human to associate with others, but the said association should mean an active encouragement and maintenance of all individual righteousness.

Luka Tomašević considers that questions about human himself, his inalienable rights, and his dignity are, in fact, questions that concern both philosophy and ethics, and states that humanity in its accelerated development has actually entered an incredible phase in which it more than ever seeks ethical values. What is required is no longer solely responsibility for one's own acts, but also responsibility for the totality of the very human species. ${ }^{21}$

15 Aristotel, Nikomahova etika. Zagreb: Hrvatska sveučilišna naklada, 1992.

16 Ibid, V, 1, 1129 a 34-V, 1, 1129 b 1.

17 Platon, Država. Beograd: Beogradski izdavačko-grafički zavod, 1976., pp. 151.

18 Ibid, pp. 369bc.

19 We could say, that a change in human consciousness is much needed, More about this in: Čović, Berislav; Marinčić, Mile, "The World Ethos Project and its contribution to inter-religious dialogue-an interdisciplinary approach“, Logos: časopis za filozofju i religiju 2(1/2014), pp. 56.-58.

20 Platon, Država, p. 151.

21 Tomašević, Luka, Bioetika iz teološke perspektive. Zagreb: Pergamena, 2014., pp. 190-191. 
Certainly, we should not omit our care and responsibility when it comes to nonhuman living beings as well. Thus, with his research "Biotička zajednica kao temelj odgovornosti za ne-ljudska živa bića" ("The Biotic Society as a Foundation of Responsibility for Non-Human Living Beings"), Ante Čović expands Kant's categorical imperative from the possible well-being for human to the entire biotic community, i.e. to all living beings:

Ontic responsibility is in a hierarchy and does not exclude the use of non-human living beings for human purposes, but it morally and legally limits and regulates it. In contrast, filonic responsibility is not in a hierarchy and it excludes the use of nonhuman living beings for human purposes. Hence, filonic responsibility by its rank fully aligns itself with moral responsibility at the level of the moral community, so that human actually has to refer to species of non-human living beings, as universal entities, as moral subjects, which means they can never be used as a means, always just as a purpose in itself. In other words, there is no obstacle at this level of responsibility for the validity of the categorical imperative to extend to the biotic community in its entirety. 22

When discussing the importance of sustainable development, Tomislav Krznar states that this subject, which includes a broad field from biology and economics to sociology, political science, and other branches of science, has been widely studied in the last decade. ${ }^{23}$ On the other hand, Tomašević states that people today say that we need to be conscious of the limitations of every science, especially experimental science, which does not provide a complete vision of life. He also says that modern science focuses on human as an object, i.e. that human life really serves as a means of possible experimental interventions on it, which opens many philosophical questions. ${ }^{24}$

Here we list important authors, such as Peter Ulrich, Hans Küng, Peter Koslowski, Hans Jonas, ${ }^{25}$ and others who gave their significant critical contribution to the questions of responsible human behaviour for the care and preservation of his own

22 Čović, Ante, „Biotička zajednica kao temelj odgovornosti za ne-ljudska živa bića“, Čović, Ante; Gosić, Nada; Tomašević, Luka (eds.), Od nove medicinske etike do integrativne bioetike. Zagreb: Pergamena : Hrvatsko bioetičko društvo, 2009., pp. 44-45.

23 Krznar, Tomislav, Znanje i destrukcija. Zagreb: Pergamena: Učiteljski fakultet Sveučilišta u Zagrebu, 2011., pp. 334.

24 Tomašević, L., Bioetika iz teološke perspektive, pp. 191.

25 For more on this see: Ulrich, Peter, Integrative Wirtschaftsethik. Grundlagen einer lebensdienlichen Ökonomie. Bern-Stuttgart-Wien: Verlag Paul Haupt, 2001.; Küng, Hans, Weltethos für Weltpolitik und Weltwirtschaft, München-Zürich: Piper, 1997. (In this paper we follow the numbering of the Croatian translation in two volumes: Svjetski ethos za svjetsku politiku i Svjetski ethos za svjetsko gospodarstvo, Zagreb: Intercon, 2007.); Koslowski, Peter, Prinzipien der Etischen Ökonomie. Grundlagung der Wirtshaftsethik und der auf die Ökonomie bezogen Ethik. Tübingen: J. C. B. Mohr (Paul Siebeck) 1988.; Jonas, Hans, Das Prinzip Verantwortung. Versuch einer Ethik für die technologische Zivilisation, Frankfurt a/M: Suhrkamp, 1979. 
future. Regarding the necessity for responsible conduct in the economy, and bearing in mind the task of philosophy as well as economics (oikos and nomos - house organization) to wisely adopt rules and regulations for the best possible life of the community and the individual, we cannot disagree with the fact that philosophy and economics are silent when discussing these agreements.

Consequently, it is necessary to rediscover awareness of issues such as entrepreneurial responsibility, the advantages of work over capital, of a just tax and social system, environmental protection, and responsible behaviour regarding technological development or gene manipulation behaviours in both human and food production. These are, as Reinhard Marx points out, concrete questions which we have to answer and decide whether the human is in the centre of all social and economic activity.

The state must, at the same time, give the individual, social groups, and organizations, in accordance with the principle of subsidiarity, a large free space for a decision, whose right to self-determination will not be limited and will not require one's own responsibility. This conception of the "dualism" of the state and society is included in the consistent directions of the Church's social doctrine. This image of the economy and society is based on the Christian image of a human who looks at a human as the moral subject with its own responsibility, and not as an atomized individual and as homo economicus fixed on its own interests. ${ }^{26}$

We take into account the views of individual economists and philosophers, starting with Adam Smith to $\mathrm{H}$. Jonas or H. Küng, which we have already mentioned above. ${ }^{27}$ In The Wealth of Nations $^{28}$, Smith advocates an ethically responsible and efficient formation of the economy in the modern age, arguing that from the moral standpoint it is not possible to evaluate inefficient economy as good. Despite numerous criticisms directed towards Smith, describing him as homo oeconomicus, without losing sight of the context of the time in which he brought forth his ideas, one cannot deny Smith's great merit in the understanding of humans, especially in relation to his 'moral feelings'. For Smith, as much as a human is egoistic and strives for his own benefit, he is still a being of empathy, i.e. he has a share in the destiny

26 Marx, Reinhard, Das Kapital: Ein Plädoyer für den Menschen. München: Pattloch Verlag \& Co. Kg, 2009., pp. 80-81.

27 In the context of care and preservation, as well as our relationship with the life and nature around us, the demands for fundamental issues such as respect and accountability are emerging. These demands are manifested through philosophical ideas such as Jonas' ethics of responsibility, Ulrich's integrative economic ethics, and Küng's project of the world ethos that are also built into the bioethical imperative of respect and responsibility to everything alive and to life as a whole, as a pledge for future generations, i.e. for the good of human. For more on this, see: Jonas, Hans, Das Prinzip Verantwortung. Versuch einer Ethik für die technologische Zivilisation, Frankfurt a/M: Suhrkamp, 1979.; Marinčić, Mile, Integrativna gospodarska etika Petera Ulricha i novija etička strujanja. Zagreb: Pergamena, 2016; Küng, Hans, Weltethos für Weltpolitik und Weltwirtschaft, München-Zürich: Piper, 1997, as well as numerous research on this subject of the professor Ivan Cifrić.

28 Smith, Adam, The wealth of nations. London: D. Campbell, 1991. 
of other people as he shows great interest in different human destinies from the day labourers to those most endangered on the brink of society. With Smith, it is really about an integrated image of a human, which as its starting point, does not take the human as the one who always acts rationally and seeks his own benefit. Smith relies on the socio-philosophical fact that individual and social human natures are referred to one another. ${ }^{29}$ In this regard, Smith offers a solution with the idea of an ethical approach of the "invisible hand". We can agree here with Marx when he rightly says that sustainability and trust are ethical values if we happen to enter a culture of distrust. If it becomes only about short-term profit maximisation, the consequences of catastrophic proportions will occur. What is emphasized is that, first of all, those most responsible for such a state have to be aware of such a black scenario, not only in terms of the moral wickedness of such egoism but also because it brings along serious economic consequences for themselves - the cause of all that. ${ }^{30}$

As Ivan Cifrić notes, up to the modern age, the same natural law applied to a human and his environment, namely the general balance, always on the boundary of preservation, the absence of surpluses. The basic needs of a human did not endanger the basic needs of the rest of the living world, as it is the case today with his secondary needs. ${ }^{31}$

By considering long-term ethics of responsibility, Jonas ${ }^{32}$ is aware of human's relationship toward the overall nature, with particular emphasis on the concern over the accelerated development and application of modern technology; according to him, no previous ethics prepared us for this. ${ }^{33}$ Human should illuminate for himself the fact that "to manage" does not mean the subordination of all-natural resources to one's own interests; on the contrary, responsible business implies the creation of the preconditions for their preservation for future generations. ${ }^{34}$

Jonas is aware that arrangements in the economy, economics, and society are an integral part of the process on which life and the world depend, and he rightly, out of responsibility for the future, places emphasis on the importance of their resolution. ${ }^{35}$

29 Ibid, see also: Marinčić, Mile, Integrativna gospodarska etika Petera Ulricha i novija etička strujanja, pp. 40-41.

30 Marx, Reinhard, Das Kapital, p. 74.

31 Cifrić, Ivan, „Trgovina životom i proširenje bioetičke tematike“, Socijalna ekologija, 7(3/1998), p. 275.

32 More about Hans Jonas and his founding of ethics of responsibility see: Jurić, Hrvoje, Etika odgovornosti Hansa Jonasa. Zagreb: Pergamena, 2010.

33 Jonas, Hans, Das Prinzip Verantwortung. Versuch einer Ethik für die technologische Zivilisation, Frankfurt a/M: Suhrkamp, 1979.

34 Ibid, p. 7.

35 According to Jonas' view of technological development, ethics is the one that has taken on itself the constitutive task of questioning human acts. See more: Jonas, Hans, Technik. Medizin und Ethik. Zur Praxis des Prinzips Verantwortung. Frankfurt am Main: Surkamp Verlag, 1987, p. 15-41, 42-52. 
According to Jonas, the main object of human responsibility has been so far the care for his own creation (city), while from the area of his responsibility, he has forgotten and lost the essential, which permanently surrounds him (nature). ${ }^{36}$

Since human has long since lost control of nature and the world in which he lives, Jonas advocates a new ethical approach that would accompany the ever-increasing changes, as well as the difficulties arising from the development of technological civilization. He is right to ask the question on what foundations and philosophical instances to build such a new concept of ethics? Jonas sees a possible answer in demand for the preservation of all humanity, which is endangered not by external threats, but by the very human, because his own ill-considered behaviour towards himself has put him in danger of disappearing. In support of this, it is enough to point out the technological progress that has reached its development in the nuclear energy, of whose force and power is superfluous to debate, and the manipulation of genes, which gives human the power to put himself in the place of the Creator himself. Through such unscrupulous human actions in technological development, the human is not offered safety and progress; on the contrary, his survival is put in jeopardy, and such actions lead to his ultimate disappearance. Jonas says we have the right to put our own lives at stake, but the lives of humankind should not be questioned. For this reason, Jonas stands for the unconditional supreme obligation of humankind to exist, not compromising what is most valuable to him, which is life. ${ }^{37}$

Küng will go a step further to say that it is a naive simplification to reduce all the difficulties of the economy to duality or profit or opinion. The ethics of success with no opinion is no ethics at all, but technique, selfish behavioural technique. It can lead to very strong libertinism and unbridled capitalism. ${ }^{38}$

Regardless if it is about politics or the economy, today more than ever, we need a vision oriented towards the future, where ethics would have the most important and primary role in decision-making. Taught by past experiences, Küng will say that today, it is difficult to expect the realisation of such a vision from the representatives of those ideologies that have served for over two hundred years as 'scientifically' complete explanations and attractive pseudo-faiths, which have so far proved to be a total failure. If we look to the left or right, we can see a bunch of failures that took place due to an uncritical approach to real problems, and it could have all been prevented if there was enough vision and responsibility in making the right and important decisions. Referring to the conversation with the successful German entrepreneur

36 Jonas, Hans, Das Prinzip Verantwortung, p. 18.

37 Ibid., pp. 59-60.

38 Küng, Hans, Svjetski ethos za svjetsko gospodarstvo, p. 123. 
Reinhold Würth, ${ }^{39}$ Küng states that 'visions are spiritual ascents between the past and the future, and that they are more than a dream, because they are substantiated by facts. By learning from past experiences, at the same time freeing himself from them, a successful visionary strives to experience the future beforehand in equal measure courageously and actually. ${ }^{40}$

Following this trail of respect for ethical values, economic ethicist Ulrich demands that ethics has to become a basis of legitimacy rather than mere words for entrepreneurial leadership. ${ }^{41}$ The task of ethics should be to make human rational in regard to the care of the world and himself, especially regarding those who are entrusted with the task of making such important decisions for the future of human. We can rightly wonder whether such a vision of the future for human well-being puts in the forefront global and not particular interests, and in regard to concluding international agreements like TTIP and CETA with justified concern, we have to ask whether the ones who sign such agreements are guided by ethical principles for the good of human. Likewise, it is necessary to ask whether agreements such as TTIP and CETA truly lead to the preservation of the good life or the benefit of large companies in order to maximize profits, to the detriment and exploitation of the most vulnerable and underdeveloped. ${ }^{42}$ It is enough to remind of the fact that more than a billion people live in the world today with less than one dollar a day, and it becomes clear why Ulrich in the challenges of the economy sees an epochal task of achieving sufficient resources for the life of the entire population. Ulrich thinks this is possible only if we strive towards a society of true, free citizens, with empowered civil rights and laws, with elementary personal rights for the realization of the real and life liberty. In order not to get the impression that it is merely about words, Ulrich gives a solution in the form of a third group of laws he calls civil-economic laws, which would give equal opportunities to everyone within the economy, not just to individuals and those who have privileges in politics and society, such as the powerful influence of large

39 About a successful vision of the development of world-renowned German entrepreneur Reinhold Würth see: Würth, Reinhold. Erfolgsgeheimnis Führungskultur. Bilanz eines Unternehmers. Frankfurt: Swiridoff Verlag, 1999, as well as on the official website of Würth: http://www.wuerth-haus-rorschach.ch/en/wuerth_management_ag haus_rorschach/portraet_2/geschichte/prof_reinholld_wuerth/prof_reinhold_wuerth.php accessed, (accessed: December 10, 2019).

40 Küng, Hans, Svjetski ethos za svjetsku politiku, pp. 17, 20-21.

41 Ibid., pp. 125-126.

42 De Ville, Ferdi, TTIP: The Truth About the Transatlantic Trade and Investment Partnership. Cambridge: Polity, 2016; Phillip Inman, "UN calls for suspension of TTIP talks over fears of human rights abuses", Guardian (4 May 2015). Available at: https://www.theguardian.com/global/2015/ may/04/ttip-united-nations-human-right-secretcourts-multinationals (accessed: January 10, 2018), see also: Tasch, Barbara, "UN human rights expert: CETA is incompatible with the rule of law, democracy, and human rights", Business Insider (accessed: October 29, 2018). Available at: http://uk.businessinsider.com/un-human-rights-expert-ceta-incompatible-with-democracy-humanrights-2016-10 (accessed: January 10, 2019). 
companies on political decisions in almost every country in the world.$^{43}$ According to Ulrich, it is understandable that in the market competition, not all can be winners, for some are bound to lose, but all must be guaranteed the same rights, as well as equal access and right to use of goods, education, bank loans, etc. In order to achieve this, more consciousness and responsibility are necessary, and such a request is, at the same time, one of the fundamental tasks of philosophical ethics. ${ }^{44}$

Today, more than ever before, the human is faced with the importance of reflection on issues of equity, solidarity, and responsibility. Regardless of which area of technological development is concerned, the human is required not only to behave responsibly but also to decide on the issue of building his own future courageously.

This is what Franz Josef Radermacher warns us of when he says that in the future we simply will not be able to meet the necessary conditions for our sustainability, such as the production of quality food, housing, drinking water, conservation of genetic diversity, and adequate climate, sea, and forest protection. These are all potential conflicts that can and have to be solved by cooperation in order to achieve consensus in reducing social inequality. ${ }^{45}$

Radermacher emphasizes responsible and correct behaviour (here we can talk about correctness in thinking before making important decisions) of all actors in society, especially those who make decisions on such important matters as negotiating and concluding international agreements. He believes that in the protection of its citizens and market, the European Union, besides a smart and balanced approach, should offer smart and well-thought-out solutions for changes, instead of the ones that have gone in the wrong direction to the benefit of not efficiency but social inequality, which is a consequence of adapting to the pressures of the world market. ${ }^{46}$

Human, if he wants to have a good life, should start and behave in accordance with such an ethical demand and realise that for the implementation of such an idea for good life, there is no room for those sensationalist demands and goals that come

43 About the elimination of unfair provisions in contracts, see: Prahalad, C. K., Bogatstvo na dnu ekonomske piramide: iskorjenjivanje siromaštva kroz profit. Zagreb: Mate : Zagrebačka škola ekonomije i managementa, 2010, pp. 94-98.

44 Ulrich, Peter, Integrative Wirtschaftsethik. Grundlagen einer lebensdienlichen Ökonomie. Bern-Stuttgart-Wien: Verlag Paul Haupt, 2001, pp, 201-210, see also: Marinčić, Mile, „O poduzetniku (bio)etičaru u okviru Ulrichova koncepta integrativne gospodarske etike“, Učenje za poduzetništvo, 1(1/2011), pp. 182-183.

45 When it comes to food production, Radermacher thinks it is necessary to think globally in the direction of efficient and high-skilled agriculture of high quality, where there would be no reduction of high standards in favor of production volume. Moreover, all this in order to meet the growing needs of the global market, i.e. where the values would be inverted, where profit, and not quality, would come to the fore. See: Radermacher, Franz Josef. Ravnoteža ili razaranje. Eko-socijalno-tržišno gospodarstvo kao ključ svjetskog održivog razvoja. Zagreb: Intercon : Nakladni zavod globus, 2003, p. 181.

46 Ibid., p. 262. While Chapter 28 also provides concrete solutions for the proper conduct of international social and trade agreements. 
overnight, with easy success and quick happiness. Likewise, in the pursuit of such a goal, we do not need any new ways or new ethics. There is already a way to a good life, and Aristotle clearly described it in Nicomachean Ethics; it is up to a human only to realise and preserve it. ${ }^{47}$

Economics, or rather economists, if they speak out, first and foremost try to stay at the level of talking of profitability, and philosophers (apart from some) seem to be uninterested in being involved in a critical discussion about the said agreements. They say that silence means approval, and the question arises of whether to approve TTIP and CETA agreements while knowing very little or nothing about them.

Ivica Kelam will take the matter further by stating that the said agreements lead all of us in the field popularly referred to as "corporate dictatorship". On the basis of TTIP analysis in Croatia, commissioned by one of our governments (to make it more absurd, the ruling party whose government commissioned such an analysis is marked as "social" in its very name), Kelam also gave a calculation that the benefit from these agreements for the Croatian GDP would ultimately be around 87 Croatian kunas per capita at best. ${ }^{48}$

\section{The contribution of the social teaching of the church}

Theologians seem to have passed over or overlooked the said agreements (TTIP and CETA) as if such interstate agreements do not concern them and their field. On the one hand, in Croatia the said is understandable, because too often theologians' engagement is interpreted as the Church's interfering in politics, and on the other hand, if individuals from the Church are involved in diverse topics concerning human, society, and the environment, to which they certainly have the right (and duty as well, we could say), then they should definitely have considered the said agreements. ${ }^{49}$ The fact is that in Croatia, the said agreements were presented "under the table", which does not mean that there is no need to look at them in a responsible, critical manner. The righteous, rightly, from the beginning, even before the floods, could rely on God as the source of righteousness. Namely, what God announced (Gen 6:18) 'But I will establish My covenant with you', now reliably executes and establishes a covenant with Noah and his sons (Gen 9:8). For the first time in Holy Scripture, a key term berît is used, which we usually know as 'covenant'. The words

47 Koprek, I., „Ekološka etika“, see: Vuleta, Bože; Vučković, Ante (ur.), Odgovornost za život, p. 40.

48 Apel za Hrvatsku slobodnu od sporazuma TTIP, CETA i TISA, available at: https://oslobodjenje-zivotinja.com/ apel-za-hrvatsku-slobodnu-od-sporazuma-ttip-ceta-i-tisa/. (accessed: December 10, 2019)

49 Kompendij socijalnog nauka Crkve, Zagreb: Kršćanska sadašnjost: Centar za promicanje socijalnog nauka Crkve Hrvatske biskupske konferencije, Komisija Hrvatske biskupske konferencije "Iustitia et pax" : Komisija Hrvatske biskupske konferencije Justitia et pax, 2005, pp, 323-346. 
of establishment in Gen 9:8-17 confirm its integrity and reliability because of berit - covenant repeats, which speaks of the persistence of the promise. Moreover, the very way of expression that speaks of establishing, raising, or founding is evidence of an institution which provides reliable support to human. Historians warn us that in the interpretation of the notion of the covenant, we should recall the vassal treaties between some power - force and a smaller ruler. Both sides took on the obligation, and the weaker would enjoy protection under the contract. At the same time, they warn us that we should always be careful with the Bible Covenant because it is not about two roughly equal parties; the fullness of God's authority is always beyond. Today, we are aware of the fact that the physical and chemical conditions of life on planet Earth are specific. Earth is a community of all of us and a planet that is given to us as the mother and father. A human is by no means the ruler of his planet and nature, but as the most perfect creature, he must reasonably govern what is given to him for the good of all. God, who is above all more powerful (Almighty - Omnipotent), is a true guardian and protector of a human and all creation. Of course, in all of this, we should not forget that a human has the freedom of choice, and therefore the possibility of renouncing the covenant. However, God's faithfulness has the final word (Hos 2:16-22), and his covenant is eternal, and his love overcomes all pitfalls (Ezek 16:60).

The agreement or the covenant offered under the TTIP or CETA has no intent to protect the weaker. Instead, it has the intent of exploitation, and it is closer to usury than to the protective character. ${ }^{50}$

Today's world, as emphasized by Tomašević, "is the world of enormous injustices, insufficient development of many peoples, the world of diverse addictions, economic, political, and ideological slavery. Proper development of the whole peoples is in a serious crisis, which creates multiple poverty" ${ }^{51}$

This is also confirmed by Gerhard Ludwig Müller, who says that today's people are anxious and sad precisely because of misery, oppression, hunger, suffering, the persecution and killing of millions of people all over the world. ${ }^{52} \mathrm{He}$ reminds us of the social encyclical of Pope Paul VI Populorum progressio (The Development of Peoples $)^{53}$, which states that hope for a better future should be based on the transition from less humane living conditions to those more humane, whose features would

50 The Criticism of the TTIP and CETA agreements we indirectly support in new lifestyles, as outlined in Kompendij socijalnog nauka Crkve, pp, 345.

51 Tomašević, Luka. Crkva pred izazovom globalizacije. Vrednovanje i kršćansko propitivanje. Zagreb: Hrvatsko filozofsko društvo, 2007, pp. 217, 220.

52 Müller, Gerhard Ludwig. Siromasttvo: izazov za vjeru. Zagreb: Kršćanska sadašnjost, 2015, p. 13.

53 Paul VI. Populorum Progressio: Encyclical Letter on the Development of Peoples, Catholic Truth Society, 1967. In this paper, we follow the numeration of the Croatian translation. 
not include only economic and technical dimensions, but the acquisition of culture and education, respect for the dignity of the other, as well as recognition of the ultimate binding values that in God at the same time have their origin and purpose. ${ }^{54}$ When it comes to accelerated human development, Müller will say that real human development should be realized within the framework of solidarity and freedom and that humanity, as a permanent and profound determinant of human being, is only possible if it is understood from faith as a manifestation of the essence of common life among people. ${ }^{55}$

An agreement cannot be cunning or preaching, but, on the contrary, an agreement has to be honest and open, as opposed to any delusion, deception, or impurity (1 Thessalonians 2:3).

It is just the same with unjust gain, which can be sweet for a while, but in the long term, it is indigestible like sand or rock (Prov 20:17). Proverbs offer us a lot of teaching on the righteousness of truth, real measure, honesty, etc.

Based on the above citations, on the basis of the Church's historical teaching (St. Augustine and St. Thomas Aquinas), ${ }^{56}$ as well as the systematic teaching of the Church on social relationships contained in the Church's social teaching, and the Compendium of the Social Doctrine of the Church, which is the best literature for introduction into the said teaching since Pope Leo XIII to this day, we can say that both theologians and the Church have not only the right but also the duty to speak of any dishonesty occurring at either the local or global level. Thus, about the said TTIP and CETA agreements as well, which, under the guise of good for all, conceal a trap of exploitation and good for the individual (one country) and, even more dangerous, they hide the threat to many, whether at the level of the economy, or at the level that will come under the guise of free trade of goods slip products that some states would certainly not want, such as GMO products. Any other direct or indirect harmful effects on society or the environment could certainly also be discussed.

When speaking of Catholic theology, the best basis for an invite for the inclusion of Catholic theologians in taking a position concerning international agreements such as TTIP or CETA is the follow-up of the teaching systematically carried out for more than one hundred and twenty years by the Catholic Church, which after the Second Vatican Council became a subject of theological studies, called the Social Doctrine

54 Müller, G. L. Siromastvo: izazov za vjeru, p. 13.

55 Ibid., pp. 13-15.

56 See more in: Čović, Berislav, Marinčić, Mile, „Društvena odgovornost za zdravo društvo u kontekstu promišljanja Küngova projekta svjetski etos“, Filozofska istraživanja, 36 (3/2016), pp. 473-491. doi:10.21464/ fi36305.; Günter, Gebhardt, „Svjetski etos kao izazov za društveni i međureligijski dijalog“, Vrhbosnensia XVI (2/2012), pp. 435-445. 
of the Church, which we have already mentioned in the previous passage. In order not to get lost in the multitude of documents issued by the Church from 1891 and the encyclical of Pope Leo XIII Rerum novarum (Of the New Things) to 2001, which are certainly valuable, we will emphasise the document of the Pontifical Council QIustitia et pax', published in Vatican in 2004 under the name of the Compendium of the Social Doctrine of the Church. ${ }^{57}$ The importance of the Compendium of the Social Doctrine of the Church is best assessed by Stjepan Baloban. He says that the Compendium should have its place in every family (home), because it is a precursor to the work of the lay faithful in political, economic, civil society life, etc. Baloban sees challenge and inspiration in the Compendium, or more specifically in the Church's social doctrine. ${ }^{58}$

Here, we will briefly present only some of the elements of Compendium that call for a reaction from theologians and the lay faithful to any threat to the principles of honesty, justice, solidarity, subsidiarity, etc., which is something agreements such as TTIP and CETA could certainly do, and therefore have to be subjected to serious criticism. In the introduction of the Compendium, it is said that humanism has to be complete and solidary, with a clear definition of the Church's role in the said process. Chapters 7 and 8 of the Compendium, which deal with economic life and the political community, are particularly important in the context of the agreements mentioned in this paper. ${ }^{59}$

Within the chapter on economic life, and in terms of the criticality of agreements such as TTIP and CETA, what is certainly important is the moral dimension of the economy, ${ }^{60}$ the economic institution in the service of human ${ }^{61}$ (of all, not individual), and the relation to globalization ${ }^{62}$ (redistribution of goods that takes care for those who have been dismissed and on edge - the common good, ${ }^{63}$ solidarity that emphasizes human rights, ${ }^{64}$ the development of civil society, ${ }^{65}$ and the importance of educational and cultural work, especially when it comes to technical and economic progress $\left.{ }^{66}\right)$.

57 Compendium of the Social Doctrine of the Church

http://www.antoniano.org/carbajo/FST/Readings/Magisterium/EN_Compendium_CST.pdf (accessed:

December 10, 2019).

58 Baloban Stjepan; Črpić Gordan. (ed.), Socijalni Kompendij: izazov i nadahnuće. Zagreb: Centar za promicanje socijalnog nauka Crkve : Kršćanska sadašnjost, 2007.

59 Kompendij socijalnog nauka Crkve, pp. $237-301$.

60 Ibid., pp. 241-245.

61 Ibid., pp. 251-259.

62 Ibid., pp. 260-269.

63 Ibid., p. 261.

64 Ibid., p. 262.

65 Ibid., p. 263.

66 Ibid., p. 269. 
In the chapter on the political community, it is clearly defined what its fundamental purpose is. Namely, the respect for the human person ${ }^{67}$ and the promotion of human rights, ${ }^{68}$ the building of coexistence based on civic friendship, ${ }^{69}$ power as a moral force, ${ }^{70}$ the right to the objection of conscience and opposition, ${ }^{71}$ the activity and value of civil society, ${ }^{72}$ democracy, ${ }^{73}$ and ultimately the emphasis is placed on the mutual separation (independence) between the Church and the political community, which does not impede their mutual cooperation and the sense to be in the service of the personal and social call of the same people ${ }^{74}$.

These elements from the Compendium are enough to ask both the lay faithful and Church officials about their position in relation to TTIP and CETA international agreements or to encourage them, if they still did not consider them, to be actively involved and to give their critical review on the subject.

G. L. Müller, referring to the constitution of the Second Vatican Council Gaudium et spes, ${ }^{75}$ says that it opens a panoramic view of the human situation in today's world and interprets: "In order to accomplish this task, the Church is obliged to question the signs of the time at all times and to interpret them in the light of gospel so as to respond to eternal human questions about the meaning of present and future life and their mutual relationship, in a way that corresponds to each individual generation (No. 4$)^{\prime \prime}{ }^{76}$

\section{Instead of conclusion}

Based on everything in the article, we can state that there was no systematic questioning of the TTIP and CETA international agreements in Croatia. We can also ascertain that the academic community, and especially the philosophers and theologians, did not excel in the analysis of the agreements, at least in the context of their subject

\footnotetext{
67 Ibid., p. 275.

68 Ibid., p. 278.

69 Ibid., p. 279.

70 Ibid., p. 283.

71 Ibid., pp. 285-287.

72 Ibid., p. 297.

73 Ibid., pp. 290-292.

74 Ibid., pp. 301-302.

75 Gaudium et spes the Pastoral Constitution on the Church in the Modern World, was adopted by the Second Vatican Council (1962-1965), and devoted precisely to the needs of the poor and those who are suffering. More in: Gaudium et spes. Pastoralna konstitucija o Crkvi u suvremenom svijetu (7. XII. 1965.). Zagreb: Hrvatsko književno društvo Sv. Ćirila i Metoda, 1968.
}

76 Müller, G. L., Siromaštvo: izazov za vjeru, p. 97. 
matter, which is questioning at the theoretical level. A bright spot in the complete silence regarding these agreements is certainly the Centre for Integrative Bioethics, which, thanks primarily to Kelam, warned of the many traps these agreements represent starting from the financial, economic, agricultural, pharmaceutical... This initiative got its concrete form in view of the international conference "Za Hrvatsku slobodnu od sporazuma TTIP/CETA/TISA" ("For Croatia Free from the TTIP/ CETA/TISA Agreements") held in Osijek on 13 and 14 October 2016 and the conference "Bioetika i okoliš - otvara li CETA vrata za GMO?" ("Bioethics and the Environment - Does CETA open the door to GMO?") held within the 1st Osijek Days of Bioethics in Osijek on 7 and 8 November 2017.

It certainly would not be good if theological and philosophical reviews and critiques of international agreements became a beautiful and ingratiatory speech, said in Derrida's manner. Philosophy and theology do not have to ingratiate themselves with anyone. Their task is not a complimentary and beautiful speech, but firm and permanent criticism whose fundamental intention is the question of good and truth. Therefore, theologians and philosophers should first insist on the systematic analysis of the said agreements, when it is not already done so by politicians, the first to be given the task and trust of the care for the common good.

\section{Acknowledgement}

This work has been created within the research program of the Scientific Centre of Excellence for Integrative Bioethics (proclaimed on November 10, 2014, by the decision of the Minister of Science, Education and Sports of the Republic of Croatia), which is being implemented at the Faculty of Humanities and Social Sciences of the University of Zagreb, as an institution hosting the Centre.

\section{BIBLIOGRAPHY}

1. Apel za Hrvatsku slobodnu od sporazuma TTIP, CETA I TISA, available at: www.oslobodjenje-zivotinja. com. http://oslobodjenje-zivotinja.com/apel-za-hrvatsku-slobodnu-od-sporazuma-ttip-ceta-i-tisa/, Accessed: December 10, 2019.

2. Aristotel, Nikomahova etika, Zagreb: Hrvatska sveučilišna naklada, 1992.

3. Baloban Stjepan; Črpić Gordan (ed.), Socijalni Kompendij: izazov i nadahnuće, Zagreb: Centar za promicanje socijalnog nauka Crkve: Kršćanska sadašnjost, 2007.

4. Capaldo, Jeronim. The Trans-Atlantic Trade and Investment Partnership: European Disintegration, Unemployment and Instability. Medford: Tufts University, 2014. Available at:

file:///F:/TTIP\%20I\%20CETA_RAD/Impact-Study-of-TTIP-on-Employment-and-Wages.pdf Accesed: December 10, 2019. 
5. Cifrić, Ivan, „Trgovina životom i proširenje bioetičke tematike“, Socijalna ekologija, 7 (3/1998), pp. 271-290.

6. Compendium of the Social Doctrine of the Church http://www.antoniano.org/carbajo/FST/Readings/ Magisterium/EN_Compendium_CST.pdf, Accessed: December 10, 2019.

7. Čović, Ante; Gosić, Nada; Tomašević, Luka (ed.), Od nove medicinske etike do integrativne bioetike. Zagreb: Pergamena: Hrvatsko bioetičko društvo, 2009.

8. Čović, Berislav, Marinčić, Mile, „Društvena odgovornost za zdravo društvo u kontekstu promišljanja Küngova projekta svjetski etos", Filozofska istraživanja, 36 (3/2016), pp. 473-491. doi:10.21464/ fi36305

9. Čović, Berislav; Marinčić, Mile, "Doprinos Projekta svjetski ethos međureligijskom dijalogu interdisciplinarni pristup”, Logos: časopis za fllozofiju i religiju, 2 (1/2014), 47-66.

10. De Bièvre, Dirk; Poletti, Arlo. „Why the Transatlantic Trade and Investment Partnership is not (so) new, and why it is also not (so) bad", Article in: Journal of European Public Policy, 24(10/2017), pp. 1506-1521. DOI: 10.1080/13501763.2016.1254274. Available at: file://F:/TTIP\%20I\%20 CETA_RAD/Why_the_Transatlantic_Trade_and_Investment_Partner.pdf (Accesed: December 10, 2019).

11. De Ville, Ferdi, TTIP: The Truth About the Transatlantic Trade and Investment Partnership. Cambridge: Polity, 2016.

12. De Zayas, Alfred-Marice, „Angela Merkel und Sigmar Gabriel wollen das Freihandelsabkommen mit den USA durchsetzen. Dabei hilft es nur den Konzernen“, Focus Magazin, (20/2016). http://www. focus.de/magazin/archiv/die-debatte-der-ttip-deal-schadet-unserer-demokratie_id_5527417.html, Accessed: January 10, 2019

13. Gaudium et spes. Pastoralna konstitucija o Crkvi u suvremenom svijetu, Zagreb: Hrvatsko književno društvo Sv. Ćirila i Metoda, 1968.

14. Grmoja, Nikola, „Ako je CETA stvarno dobra, zašto to nismo mogli potvrditi?“, Večernji list, 4.7.2017.

15. Günter, Gebhardt, „Svjetski etos kao izazov za društveni i međureligijski dijalog“, Vrhbosnensia, XVI (2/2012), pp. 435-445.

16. Inman, Phillip, "UN calls for suspension of TTIP talks over fears of human rights abuses", The Guardian (4 May 2015). Available at: https://www.theguardian.com/global/2015/ may/04/ ttip-united-nations-human-right-secret-courts-multinationals (accessed: January 10, 2018).

17. Jonas, Hans, Das Prinzip Verantwortung. Versuch einer Ethik für die technologische Zivilisation, Frankfurt a/M: Suhrkamp, 1979.

18. Jonas, Hans, Technik. Medizin und Ethik. Zur Praxis des Prinzips Verantwortung, Frankfurt am Main: Surkamp Verlag, 1987.

19. Jurić, Hrvoje, Etika odgovornosti Hansa Jonasa, Zagreb: Pergamena, 2010.

20. Kelam, Ivica, „Investor to State Dispute Settlement. A Challenge for Democracy, Ethics, the Environment, and the Rule of Law", Synthesis philosophica, 34 (1/2019), pp. 59-71.

21. Kelam, Ivica, „Planet na prodaju - socijalno-etičko razmatranje fenomena grabeža zemlje“, Obnovljeni život, 70 (1/2015), pp. 101-113.

22. Kompendij socijalnog nauka Crkve, Zagreb: Kršćanska sadašnjost : Centar za promicanje socijalnog nauka Crkve Hrvatske biskupske konferencije, Komisija Hrvatske biskupske konferencije "Iustitia et pax" : Komisija Hrvatske biskupske konferencije Justitia et pax, 2005.

23. Koprek, Ivan, „Ekološka etika“, u: Vuleta, Bože; Vučković, Ante (ur.), Odgovornost za život. Zbornik. Baška Voda: Franjevački institut za kulturu mira, 2001., pp. 31-43.

24. Koslowski, Peter, Prinzipien der Etischen Ökonomie. Grundlagung der Wirtshaftsethik und der auf die Ökonomie bezogen Ethik. Tübingen: J. C. B. Mohr (Paul Siebeck) 1988.

25. Krznar, Tomislav, Znanje i destrukcija, Zagreb: Pergamena: Učiteljski fakultet Sveučilišta u Zagrebu, 2011.

26. Küng, Hans, Projekt svjetski etos, Velika Gorica: Miob naklada, 2003. 
27. Küng, Hans. Svjetski ethos za svjetsko gospodarstvo, Zagreb: Intercon, 2007.

28. Küng, Hans. Svjetski ethos za svjetsku politiku, Zagreb: Intercon, 2007.

29. Küng, Hans, Weltethos für Weltpolitik und Weltwirtschaft, München-Zürich: Piper, 1997.

30. Marinčić, Mile, Integrativna gospodarska etika Petera Ulricha i novija etička strujanja, Zagreb: Pergamena, 2016.

31. Marinčić, Mile, „O poduzetniku (bio)etičaru u okviru Ulrichova koncepta integrativne gospodarske etike“, Učenje za poduzetništvo, 1(1/2011), pp. 177-195.

32. Marx, Reinhard, Kapital: Ein Plädoyer für den Menschen. München: Pattloch Verlag \& Co. Kg, 2009.

33. Mertins-Kirkwood, Hadrian; Sinclair, Scott; Trew, Stuart (edt.). Making Sense of CETA. An analysis of the final text of the Canada-European Union Comprehensive Economic and Trade Agreement. 2nd edition. Berlin/Ottawa: PowerShift: CCPA et al., 2016. Available at: http://s2bnetwork.org/wpcontent/uploads/2018/11/Making-sense-of-CETA-2018.pdf (Accessed: December 10, 2019).

34. Müller, Gerhard Ludwig, Siromaštvo: izazov za vjeru, Zagreb: Kršćanska sadašnjost, 2015.

35. Mužić, Josip. Rat protiv čovjeka, Zagreb: Glas koncila, 2015.

36. Papinsko vijeće "Iustitia et pax «, Kompendij socijalnog nauka Crkve, Zagreb: Kršćanska sadašnjost, 2005.

37. Persson, Ingmar; Savulescu, Julian. "Unfit for the future? Human Nature, Scientific Progress, and the Need for Moral Enhancement", in: Savulescu, Julian, ter Meulen, Ruud; Kahane, Guy (edt.), Enhancing Human Capacities, Oxford: Wiley-Blackwell, 2011., pp. 486-499.

38. Persson, Ingmar; Savulescu, Julian, Unfit for the future. The Need for Moral Enhancement, Oxford: Oxford University Press, 2012.

39. Paul VI. Populorum Progressio: Encyclical Letter on the Development of Peoples, Catholic Truth Society, 1967.

40. Platon, Država, Beograd: Beogradski izdavačko-grafički zavod, 1976.

41. Prahalad, Coimbatore Krishnarao, Bogatstvo na dnu ekonomske piramide: iskorjenjivanje siromaštva kroz profit, Zagreb: Mate: Zagrebačka škola ekonomije i managementa, 2010.

42. Radermacher, Franz Josef, Ravnoteža ili razaranje. Eko-socijalno-tržišno gospodarstvo kao ključ svjetskog održivog razvoja, Zagreb: Intercon : Nakladni zavod globus, 2003.

43. Raza, Werner (project leader); Grumiller, Jan; Taylor, Lance; Tröster, Bernhard; von Arnim, Rudi. ASSESS_TTIP: Assessing the claimed benefits of the Transatlantic Trade and Investment Partnership (TTIP): Final Report. Vienna: ÖFSE, 2014. Available at: https://www.researchgate.net/ publication/265301168_ASSESS_TTIP_Assessing_the_claimed_benefits_of_the_Transatlantic_ Trade_and_Investment_Partnership Accessed: December 10, 2019.

44. Romić, Tea, „Bunjac: „Sporazum CETA je antihrvatski“, Večernji list, 30.6.2017.

45. Smith, Adam, The wealth of nations. London: D. Campbell, 1991.

46. Sučec, Nikola, „Sporazum o trgovini s Kanadom je potpisan - što to znači za Hrvatsku“, Večernji list, 31.10.2016.

47. Šimleša, Dražen, „Biotehnologija kao oblik kontrole“, Socijalna ekologija, 13(1/2004), pp. 25-44.

48. Tomašević, Luka, Bioetika iz teološke perspektive, Zagreb: Pergamena, 2014.

49. Tomašević, Luka, Crkva pred izazovom globalizacije. Vrednovanje i kršćansko propitivanje, Zagreb: Hrvatsko filozofsko društvo, 2007.

50. Troszczynska-Van Genderen, Wanda; Bierbrauer, Elfriede, The Transatlantic Trade and Investment Partnership (TTIP): The US Congress's positions. Brussels: Policy Department External Policy European Parliament, 2014. http://www.europarl.europa.eu/RegData/etudes/BRIE/2014/536395/ EXPO_BRI(2014)536395_EN.pdf, Accessed: January 10, 2019.

51. Ulrich, Peter, Integrative Wirtschaftsethik. Grundlagen einer lebensdienlichen Ökonomie. Bern-StuttgartWien: Verlag Paul Haupt, 2001. 
52. Vizjak, Ana, Vizjak, Maja. "Pregovori o Transatlantskoj trgovini i ulaganju (TTIP) i regulacija financija financijskog tržišta“, Ekonomska misao i praksa, (1/2016), pp. 319-336.

53. Vuleta, Bože; Vučković, Ante (ed.), Odgovornost za život, Baška Voda: Franjevački institut za kulturu mira, 2001.

54. Würth, Reinhold. Erfolgsgeheimnis Führungskultur. Bilanz eines Unternehmers. Frankfurt: Swiridoff Verlag, 1999.

\section{Etički pogled na međunarodne trgovinske sporazume TTIP i CETA u Republici Hrvatskoj}

\section{SAŽETAK}

Gotovo je šaptom prošla tema TTIP-a i CETA-e u Hrvatskoj. Radi se o vrlo važnim međunarodnim sporazumima koji mogu imati dalekosežne posljedice, kako na svijet, tako i na pojedine države. Možda Hrvatska, kao i EU, nije toliko involvirana u cijelu priču kada se radi o TTIP-u. CETA je, međutim, sporazum koji je Kanada potpisala s Europskom unijom, stoga se nakon odobrenja Europskog parlamenta mogu odmah početi primjenjivati odredbe koje su u nadležnosti EU-a, poput carinske politike, a to znači ukidanje carine za 99\% proizvoda već od 1. siječnja 2017. Postupak za sklapanja CETA-e u ime Hrvatske pokrenula je tehnička vlada Tihomira Oreškovića na svojoj posljednjoj sjednici, a za razliku od američko-europskog trgovinskog sporazuma - TTIP-a koji je neslavno propao, CETA je ipak „prošla“. Površno tumačenje ovih nikako bezazlenih sporazuma premalo zanima i filozofe i teologe u Hrvatskoj; osim što se Centar izvrsnosti za integrativnu bioetiku oglasio po ovom pitanju, drugih filozofsko-teoloških rasprava kao da nema. Doima se kako filozofi i teolozi smatraju da se ova pitanja njih ne tiču. U radu ćemo pokušati dati do znanja kako se navedeni međunarodni sporazumi i te kako dotiču i filozofa i teologa, te kako bi se oni iz svog polja na teorijskoj razini svakako trebali uključiti u raspravu o njima.

Ključne riječi: međunarodni trgovinski sporazumi, TTIP, CETA, Hrvatska, filozofija, teologija, izazovi, posljedice 